\title{
Directors' Political Connections and Compliance with Board of Directors Regulations: The Case of S\&P/Tsx 300 Companies
}

\author{
Hanen Khemakhem ${ }^{1} \&$ Saidatou Dicko ${ }^{1}$ \\ ${ }^{1}$ Department of accounting, School of management, Université du Québec à Montréal, Canada \\ Consepondence: Hanen Khemakhem, Department of accounting, School of management, Université du Québec \\ à Montréal, Canada. E-mail: khemakhem.hanen@uqam.ca
}

Received: September 17, 2013

Accepted: November 13, 2013

Online Published: November 18, 2013

doi:10.5539/ijbm.v8n24p117

URL: http://dx.doi.org/10.5539/ijbm.v8n24p117

\begin{abstract}
Further to the various scandals that shook North-American markets in the early 2000s, Canada reacted in 2004 and 2005 by changing its regulations on the governance practices of listed companies. Faccio (2006) and other authors have argued that politically connected companies can have less regulatory oversight than unconnected firms. This affirmation raises an issue that this article attempts to solve, i.e., whether politically connected Canadian companies are less compliant with regulatory requirements on governance than unconnected firms, and with board of directors requirements in particular. Although politically connected and unconnected firms differ significantly in their compliance with regulation, the analyses show that the state of being politically connected tends to have little bearing on regulatory compliance.
\end{abstract}

Keywords: board of directors, Canada, governance, political connections, regulation

\section{Introduction}

Corporate governance is assured through a number of structures and mechanisms that reconcile the divergent interests of officers and shareholders. Different governance mechanisms are instituted to maximize the value of the firm (Agrawal \& Knoeber, 1996), ensure better returns and limit the transfer of wealth among shareholders and officers so as to reduce the risk of total shareholder loss (Parrat, 2003).

Further to the various scandals that shook North-American markets in the early 2000s, Canada reacted in 2004 and 2005 by changing its regulations on the governance practices of listed companies. (Note 1)

The objective of the Canadian regulations was to restore investor confidence in the Canadian financial market and ensure the protection of investments while remaining open to changes in governance trends in the United States and the rest of the world. (Note 2) Given that most of these regulations are voluntary, it is relevant to investigate the factors that influence compliance decisions by Canadian firms.

Quality of corporate governance is understood to depend on the institutional and regulatory environments of countries (Claessens \& Yurtoglu, 2012; LaPorta, Lopez-de-Silanes, Shleifer \& Vishny 1998; Liu, 2006; Matoussi \& Jardak, 2012). However, regulation and its application are factors strongly influenced by political power (Claessens \& Yurtoglu, 2012). Faccio (2006) and other authors have maintained that politically connected companies can have less regulatory oversight than unconnected firms. This affirmation raises an issue that this article attempts to solve, i.e., whether politically connected Canadian companies are less compliant than unconnected firms in regard to regulatory requirements on governance, and on the board of directors in particular.

\section{Canadian Institutional Context}

The Canadian financial market has undergone dramatic legal, institutional and operational changes since the beginning of 2000 (Carnaghan \& Gunz, 2007). Prior to these changes, the Toronto Stock Exchange (TSE) had implemented the recommendations of the Dey Report, based on the conclusions of a committee of inquiry helmed by Peter Dey. (Note 3) The TSE's approach was founded on self-regulation, with no prescriptions to conform to the report's guidelines (Rousseau \& Talbot, 2007).

In 2004 and 2005, a set of national policies and regulations were instituted to regulate some governance practices in Canada; most notably National Instrument 52-110 Audit Committees and National Policy 58-201 
Corporate Governance Guidelines. These regulations apply to all listed companies in Canada and contain several recommendations about the nature and operations of the board of directors.

In a departure from tradition, this last reform sent a mixed message of tolerance and lack of constraint on the one hand and absolutism on the other; hence its characterization by Rousseau and Talbot (2007) as a middle-ground measure. Adopters of National Policy 58-110 are free to apply best practices as convenient, as the guidelines it contains are not prescriptive. Firms are responsible only for producing a comparative table outlining how they implemented the policy, or else declare their non-implementation (along with their reasons).

The prescriptive text is National Instrument 52-110 on Audit Committees. Application of this regulation was mandatory beginning on the first annual meeting held after July 2004, with the final deadline being July 2005.

The reform's most tolerant aspect is reflected in National Policy 58-201 Corporate Governance Guidelines, which came into force in June 2005. The policy recommends best governance practices such as board and chairperson independence, separate meetings for independent administrators, and the establishment of a written charter delineating the board's role.

\section{Literature Review and Hypotheses}

According to several authors, the level and quality of corporate governance and the level of protection of investor interests depend on institutional factors, the country's level of development, and ownership structure (Claessens \& Yurtoglu, 2012; LaPorta et al., 1998; Liu, 2006; Matoussi \& Jardak, 2012). The basic premise behind these studies is that a legal system that properly fulfills its functions protects external investors, which in turn helps improve the firm's ability to increase its external financing and make the most of its opportunities for growth. Indeed, as underlined by Hail and Leuz (2006), the strong protection of outside investors limits their expropriation by top officers.

However, politics is one of the key determinants of a country's institutional landscape. According to Faccio (2006), many firms around the world are politically connected. Studies have demonstrated that being politically connected can result in numerous privileges for firms and lead to their improved financial performance (Dinc, 2005; Charumilind, Kali, \& Wiwattanakantang, 2006; Faccio, 2006; Claessens, Underhill, \& Zang, 2008; Goldman, Rocholl, \& So, 2009; Dicko \& Breton, 2013; Dicko \& El Ibrami, 2013).

Thus, Dinc (2005), in a study of emerging countries, showed that banks in which the government had at least a $20 \%$ stake increased their loans by $11 \%$ at election time, with the goal of serving the interests of politicians and politically connected firms.

Charumilind et al. (2006) argued that politically connected companies have greater access than unconnected firms to long-term debt in Thailand.

Claessens et al. (2008) studied a sample of Brazilian companies and found that firms that contributed financially to the coffers of elected officials during the 1998 and 2002 electoral races experienced an increase in market returns compared with those that did not make such contributions.

Goldman, Rocholl, \& So (2009) examined the effects of the political connections of S\&P 500 companies and concluded that firms that appointed a politically connected person to their board experienced market returns at the time of the announcement of the nomination. In addition, companies connected to the Republic Party at the time of the 2000 US elections increased in value, while those connected to the Democratic Party had the opposite experience.

From an OSISRIS data base sample of top 100 Canadian firms, Dicko \& Breton (2013) showed that directors' political connections have a positive and significant link with financial performance (measured by return on assets). Furthermore, Dicko \& El Ibrami (2013) concluded that directors' political connections influence positively and significantly the long term debt increase, on a Compustat randomly selected sample of 300 Canadian companies.

According to Faccio (2006), politically connected firms can have lighter taxation, preferential treatment in competition for government contracts or relaxed regulatory oversight than unconnected firms. So far few studies have examined the link between political connections and regulatory compliance, especially in the Canadian context. The present study aims to fill this gap, particularly as regards regulations that have both mandatory and elective components.

In view of the foregoing, and given the influence of political connections and the elective aspect of the board of directors' regulations under study, it is expected that: 
$H_{1}$ : Politically connected firms are less likely than unconnected firms to comply with board of directors regulations. More specifically, $H_{1 a}$ : Politically connected firms are less likely to comply with regulations on specific characteristics of the board of directors.

$H_{l b}$ : Politically connected firms are less likely to comply with regulations on the structure and operation of board of directors committees.

\section{Methodology}

\subsection{Sample}

This study was conducted on TSX 300 firms in 2010, i.e., five years after the regulations came into force (2005). By then companies had had the time to make adjustments and weather the 2008 crisis. For the investigation, financial data were pulled from COMPUSTAT. Board of directors data were collected using information from directors' circulars and annual notices available on Sedar.com. Data on board of directors' political connections were collected from company websites and the SEDAR database. The sample data are presented in Table 1.

Table 1. Sample selection

\begin{tabular}{ll}
\hline & Number \\
\hline S\&P\TSX 300 & 245 \\
Merger and acquisition & 4 \\
Missing data & 9 \\
Final sample & 199 \\
\hline
\end{tabular}

\subsection{Model and Analyses}

The main goal of this study was to compare and contrast compliance with regulations on the board of directors by politically connected and unconnected firms. Variance analysis (ANOVA) was used for this purpose.

Based on the research hypotheses whereby such compliance is influenced by a firm's political connections via its directors, the following linear regression model was used:

$$
\text { Compliance }=\text { Political Connections + Indebtedness + Firm Size + Sector + US Market Value }
$$

Where:

-Compliance is the board's level of conformance to Canadian regulations on the board of directors (30-points index);

-Political connections take the value of 1 if at least one of the firm's directors is or has been a member of parliament, works for the government, belongs to a political party or has made a financial contribution to a political party;

-Size is the logarithm of the firm's assets in 2010;

-US market value takes the value of 1 if the firm is subject to US stock exchange regulations, and 0 otherwise;

-Sector is the firm's industry group as defined in SEDAR. Nine sectors were identified and coded 1 to 9;

-Indebtedness is measured by the long-term debt to total assets ratio.

\subsection{Measurement of Variables}

\subsubsection{Dependent Variable: Compliance with Canadian Regulations}

Levels of conformance to Canadian regulations on the board of directors was measured through a 30-points index, consistent with other studies that used similar indices (Gombers, Ishii \& Metrick, 2003; Defond, Hann \& $\mathrm{Hu}, 2005$; Bhagat \& Bolton, 2008). The index was validated previously by financial experts and used in other studies (Khemakhem \& Naciri, 2011; Khemakhem, Baillargeon \& Gélinas, 2013).

It provides the advantage of a better global measurement and comparability among firms (Bhagat, Bolton \& Romano, 2008). For this study, an objective frame of reference tailored to the Canadian context was selected: National Policy 58-201 and National Instrument 52-110, adopted by financial market authorities in Canada.

National Policy 58-201 provides examples of best governance practices such as board and chairman independence, separate meetings for independent directors and the existence of a written charter (Note 4) and a 
code of ethics. This regulation provides a source of compliance points in regard to board of directors and committee characteristics (see Appendix containing the measurement grid).

The index was further enriched by National Instrument 52-110 Audit Committees, which stipulates the use of independent external auditors and an independent audit committee. This regulation provides a source of compliance points in regard to the audit committee and the independence of board members and committees.

\subsubsection{Measurement of the "Political Connections" Independent Variable}

The literature defines the firm's political connections in various ways. According to Faccio (2006) and other authors (Boubakri, ElGoul \& Saffar, 2012), a firm is politically connected if its majority shareholder or one of its officers or directors is a member of parliament, a minister or government leader, or is politically connected (through family ties or friendships, for example).

In addition, a firm is politically connected if it contributes financially to a political party, according to Dinc (2005), Claessens et al., (2008) and Goldman et al., (2009).

The present study looks at the firm's political connections by way of its directors, using criteria found in the literature (particularly Faccio, 2006; Goldman et al., 2009) and applying them to a single director. Thus, the variable takes the value of 1 if at least one director is or has been a member of the government or parliament, has contributed financially to a party or is a member of a political party.

\subsubsection{Model Control Variable}

The firm's characteristics impact on the level and quality of governance as well as the institutional context. For example, Aggarwal, Erel, Stulz, \& Williamson (2009) demonstrated that the following variables characterizing the firm impact on its governance: size (measured by the logarithm of its assets), long-term debt divided by total assets, and industry sector.

Similar to Aggarwal et al. (2009), the current investigation used the following control variables: firm size (measured by the logarithm of sales), relative indebtedness (measured by long-term debt divided by total assets), and industry sector (measured by a dummy variable coded 1 to 9). The firm's US market value was also taken into consideration. Given that a number of Canadian firms were subject to US regulations as a result of being listed on the US stock exchange, and that US regulations are considered to be considerably more stringent, the firm's listing on the US market was included as a control variable.

\section{Results and Discussion}

Variance analysis (ANOVA) was used to study the difference between politically connected and unconnected firms in terms of their compliance with regulations on the board of directors.

Thereafter, linear regressions helped determine whether the fact of being politically connected influences the firm's compliance with regulations on the board of directors.

\subsection{Compliance and Political Connection Indices}

For this study, several indices were developed to measure compliance from the aspect of:

- The board of directors (board of directors score);

- Board committees other than audit (committee score); (Note 5)

- Total compliance (Total score).

The mean results for the variance analysis are presented in Table 2. 
Table 2. ANOVA-political connection

\begin{tabular}{ccccccc}
\hline & & Summ Square & ddl & Mean Square & F & Signification \\
\hline \multirow{4}{*}{ Board index } & Inter-groups & 5,570 & 1 & 5,570 & 4,658 & $0,032^{* *}$ \\
& Intra-groups & 229,589 & 192 & 1,196 & & \\
& Total & 235,160 & 193 & & & \\
Audit committee & Inter-groups & 0,085 & 1 & 0,085 & 2,852 & $0,093 *$ \\
index & Intra-groups & 5,729 & 192 & 0,030 & & \\
& Total & 5,814 & 193 & & & 0,127 \\
Other committees & Inter-groups & 26,163 & 1 & 26,163 & 2,345 & \\
index & Intra-groups & 2142,090 & 192 & 11,157 & & $0,062 *$ \\
& Total & 2168,253 & 193 & & & \\
Total index & Inter-groupes & 51,727 & 1 & 51,727 & 3,522 & \\
& Intra-groupes & 2819,515 & 192 & 14,685 & & \\
\hline
\end{tabular}

Table 2 shows a general and significant difference between politically connected and unconnected firms in their conformance to regulations on the board of directors (significant total score). Taken individually, only the difference in conformance relative to other committees appears to be non-significant among politically connected and unconnected firms (other committees score). This is simply because regulations about other committees are recommendations rather than prescriptions. However, this study's hypotheses are still not confirmed because the manner in which political connections influence conformance to regulations is unknown. To answer that question, regression analyses were performed.

\subsection{Analysis of Linear Regressions of Compliance and Political Connection Scores}

An analysis was performed of the three aforementioned scores: board of directors, other committees (other than the audit committee) and total score (board and all its committees).

\subsubsection{Relationship between Board of Directors Score and Political Connections}

Contrary to predictions, political connections positively influence compliance with regulations on the board of directors (Table 3). This could be explained by the fact that given their probable political exposure and visibility, firms with political connections have an interest in using the very best of practices in regard to regulations so they can avoid being accused of conflicts of interest and favouritism.

Table 3. Linear regression results dependent variable: board score

\begin{tabular}{|c|c|c|c|c|c|}
\hline \multirow[t]{2}{*}{ Model } & \multicolumn{2}{|c|}{ Unstandardized Coefficients } & \multirow{2}{*}{$\begin{array}{c}\text { Standardized } \\
\text { Coefficients }\end{array}$} & \multirow[t]{2}{*}{$\mathrm{t}$} & \multirow[t]{2}{*}{ Sig. } \\
\hline & $\mathrm{A}$ & Standard Error & & & \\
\hline (Intercept) & 7,106 & 0,391 & & 18,17 & $0,000 * * *$ \\
\hline Firm size & 0,026 & 0,052 & 0,036 & 0,500 & 0,618 \\
\hline Debt Ratio & 1,371 & 0,561 & 0,203 & 2,445 & $0,015^{* *}$ \\
\hline Political Connection & 0,254 & 0,174 & 0,107 & 1,458 & 0,147 \\
\hline Industry & $-0,010$ & 0,023 & $-0,035$ & $-0,423$ & 0,673 \\
\hline US & 0,550 & 0,166 & 0,241 & 3,304 & $0,001 * * *$ \\
\hline $\mathrm{R} 2$ & & & & 0,047 & \\
\hline Adjusted R2 & & & & 0,027 & \\
\hline
\end{tabular}

\subsubsection{Relationship between Total Score and Political Connections}

According to Table 4, political connections also have a positive, albeit non-significant, impact on compliance with regulation, for the same reasons given for the preceding score. 
Table 4. Linear regression results dependent variable: total score

\begin{tabular}{|c|c|c|c|c|c|}
\hline \multirow[t]{2}{*}{ Model } & \multicolumn{2}{|c|}{ Unstandardized Coefficients } & \multirow{2}{*}{$\begin{array}{c}\text { Standardized } \\
\text { Coefficients }\end{array}$} & \multirow[t]{2}{*}{$\mathrm{t}$} & \multirow[t]{2}{*}{ Sig. } \\
\hline & A & Standard Error & & & \\
\hline (Intercept) & 17,883 & 1,374 & & 13,018 & $0,000 * * *$ \\
\hline Firm size & 0,418 & 0,183 & 0,168 & 2,289 & $0,023 * *$ \\
\hline Debt Ratio & 0,425 & 1,969 & 0,018 &, 216 & 0,829 \\
\hline Political Connection & 0,653 & 0,613 & 0,078 & 1,066 & 0,288 \\
\hline Industry & $-0,109$ & 0,082 & $-0,109$ & $-1,319$ & 0,189 \\
\hline US & 1,463 & 0,585 & 0,183 & 2,503 & $0,013 *$ \\
\hline $\mathrm{R} 2$ & & & & 0,061 & \\
\hline Adjusted R2 & & & & 0,040 & \\
\hline
\end{tabular}

\subsubsection{Relationship between the Scores for Other Committees and Political Connections}

The results for this category are similar to those obtained for the relationship between political connections and compliance with regulation.

Table 5. Linear regression results dependent variable: score total other committees

\begin{tabular}{|c|c|c|c|c|c|}
\hline \multirow{2}{*}{ Model } & \multicolumn{2}{|c|}{ Unstandardized Coefficients } & \multirow{2}{*}{$\begin{array}{c}\begin{array}{c}\text { Standardized } \\
\text { Coefficients }\end{array} \\
\text { Bêta }\end{array}$} & \multirow{2}{*}{$\mathrm{t}$} & \multirow{2}{*}{ Sig. } \\
\hline & $\mathrm{A}$ & $\begin{array}{c}\text { Standard } \\
\text { Error }\end{array}$ & & & \\
\hline (Intercept) & 5,797 & 1,195 & & 4,851 & $0,000 * * *$ \\
\hline Firm size & 0,384 & 0,159 & 0,178 & 2,419 & $0,017 * *$ \\
\hline Debt ratio & $-0,715$ & 1,713 & $-0,035$ & $-0,418$ & 0,677 \\
\hline Political connection & 0,453 & 0,533 & 0,063 & 0,851 & 0,396 \\
\hline Industry & $-0,111$ & 0,072 & $-0,128$ & $-1,545$ & 0,124 \\
\hline US & 0,873 & 0,509 & 0,126 & 1,717 & $0,088^{*}$ \\
\hline $\mathrm{R} 2$ & & & & 0,083 & \\
\hline Adjusted R2 & & & & 0,058 & \\
\hline
\end{tabular}

\subsection{Sensitivity Analysis}

Given that a number of Canadian firms are subject to mandatory US regulations, it was decided that this variable should be eliminated from the model when performing the analyses. The results obtained were roughly the same, and were not tabulated.

\section{Conclusion}

The Canadian financial market has undergone numerous changes since 2000 (Carnaghan \& Gunz, 2007). The early 2000s were marked by a series of financial scandals that shook the confidence of investors and required lawmakers and regulatory bodies to intervene and shore up several aspects of governance among listed firms. These events prompted changes in the regulations on the corporate governance practices of Canadian firms, beginning with the board of directors and its committees. (Note 6)

The goal of this research was to study the relationship between compliance with Canadian regulations on characteristics of the board of directors and its committees, and the firm's political connections.

Although a significant difference was noted in the compliance levels of politically connected and unconnected firms, the results of the analyses did not overwhelmingly demonstrate the impact of political connections. In terms of compliance with regulations on the board of directors, firm size and listing on the US market are the two foremost determining factors. Political connections may lead to the adoption of best practices as a way of avoiding accusations of favouritism or potential conflicts of interest. In cases of non-compliance, firms risk being penalized on the financial markets (Gompers et al., 2003), and as a result may see an increase in financing costs (Khemakhem \& Naciri, 2011). 
This study has some limitations. The most widespread variables in the literature were used to explain compliance with governance regulations despite the fact that the Canadian context has a strong concentration of ownership and controlling shareholders (Bozec \& Laurin, 2007). Some studies (Klein, Shapira \& Young CGIR, 2005; Bozec \& Bozec, 2007) showed that ownership structure could be a determining factor in the quality of corporate governance mechanisms. Future research may benefit from focussing on ownership structure along with political connections.

\section{References}

Aggarwal, R., Erel, I., Stulz, R., \& Williamson, R. (2009). Differences in governance practices between U.S. and foreign firms: measurement, causes, and consequences. The Review of Financial Studies, 22(8), 3132-3169. http://dx.doi.org/10.1093/rfs/hhn107

Agrawal, A., \& Knober, C. (1996). Firm Performance and Mechanisms to Control Agency Problems Between Managers and Shareholders. Journal of Financial and Quantitative Analysis, 31(3), 377-397.

Bhagat, S., \& Bolton, B. (2008). Corporate Governance and Firm Performance. Journal of Corporate Finance, 14, 257-273.

Bhagat, S., Bolton, B., \& Romano, R. (2008). The Promise and Peril of Corporate Governance Indices. Columbia Law Review, 108(8), 1803-1882.

Boubakri, N., ElGoul, S., \& Saffar, W. (2012). Cash Holdings of Politically Connected Firms. The International Journal of Accounting Symposium. Toronto: NiagaraFalls.

Bozec, Y., \& Bozec, R. (2007). Ownership concentration and corporate governance practices: substitution or expropriation effects? Canadian Journal of Administrative Sciences, 24(3), 182-195.

Bozec, Y., \& Laurin, C. (2008). Large Shareholder Entrenchment and Performance: Empirical Evidence from Canada. Journal of Business Finance \& Accounting, 35(1/2), 25-49.

Carnaghan, C., \& Gunz, S. (2007). Recent Changes in the Regulation of Financial Markets and Reporting in Canada. Accounting Perspective, 6(1), 55-94.

Chaney, P. K., Faccio, M., \& Parsley, D. C. (2011). The quality of accounting information in politically connected firms. Journal of Accounting and Economics, 51(1), 58-76.

Charumilind, C., Kali, R., \& Wiwattanakantang, Y. (2006). Connected lending: Thailand before the financial crisis. Journal of Business, 79, 181-217.

Claessens, S., Underhill, G., \& Zang, X. (2008). The Political Economy of Basle II: The Costs for Poor Countries. The World Economy, 31(3), 313-344.

Claessens, S., \& Yurtoglu, B. B. (2012). Corporate governance in emerging markets: a survey. Emerging Markets Review.

Defond, M. L., Hann, R. N., \& Hu, X. (2005). Does the Market Value Financial Expertise on Audit Committees of Boards of Directors? Journal of Accounting Research, 43(2), 153-193.

Dicko, S., \& Breton, G. (2013). Do directors' connections really matter? International Academic Research Journal of Business and Management, 1(7), 1-19.

Dicko, S., \& El Ibrami, H. (2013). Directors' Connections, Financial Resources and Performance: An In-Depth Analysis of Canadian Companies. International Journal of Business and Management, 8(10), 1-14. http://dx.doi.org/10.5539/ijbm.v8n10p1

Dinc, I. S. (2005). Politicians and banks: Political influences on government-owned banks in emerging markets. Journal of Financial Economics, 77, 453-479.

Faccio, M. (2006). Politically connected firms. The American Economic Review, 96(1), 369-386.

Faccio, M., Masulis, R. W., \& Mcconnell, J. J. (2006). Political Connections and Corporate Bailouts. The Journal of Finance, 16(6), 2597-2635.

Fisman, R. (2001). Estimating the value of political connections. The American Economic Review, 91(4), 1095-1102.

Goldman, E., Rocholl, J., \& So, J. (2009). Do Politically Connected Boards Affect Firm Value? The Review of Financial Studies, 22(6), 2331-2360. http://dx.doi.org/10.1093/rfs/hhn088 
Gombers, P., Ishii, J., \& Metrick, A. (2003). Corporate Governance and Equity Prices. The Quarterly Journal of Economics, 107-155.

Hail, L., \& Leuz, C. (2006). International Differences in the Cost of Equity Capital: Do Legal Institutions and Securities Regulation Matter. Journal of Accounting Research, 44(3), 437-483. http://dx.doi.org/10.1111/j.1475-679X.2006.00209.x

Khemakhem, H., \& Naciri, A. (2011). Changement de la réglementation relative au conseil d'administration et ses comités et coût du capital des entreprises canadiennes. CAAA Annual Conference, Toronto, Ontario.

Khemakhem, H., Baillargeon, L., \& Gélinas, P. (2013). Catalysis for Change in Board Governance Practices: The Case of the Introduction of National Policy 58-201 in Canada. ASAC, Calgary, BC.

Klein, P., Shapiro, D., \& Young, J. (2005). Corporate Governance, Family Ownership and Firm Value: the Canadian evidence. Corporate Governance: An International Review, 13, 769-784.

LaPorta, R., Lopez-de-Silanes, F., Shleifer, A., \& Vishny, R. W. (1998). Law and Finance. Journal of Political Economy, 106(6), 1113-1155.

LaPorta, R., Lopez-De-Silanes, F., Shleifer, A., \& Vishny, R. W. (1997). Legal Determinants of External Finance. The Journal of Finance, 52(3), 1131-1151.

LaPorta, R., Lopez-De-Silanes, F., \& Shleifer, A. (2006). What Works in Securities Laws? The Journal of Finance, 61(1), 1-32

Liu, Q. (2006). Corporate Governance in China: Current Practices, Economic Effects and Institutional Determinants. CESifo Economic Studies, 52(2), 415-453.

Matoussi, H., \& Khemakhem-Jardak, M. (2012). International Corporate Governance and Finance: Legal, Cultural and Political Explanations. The International Journal of Accounting, 47, 1-43.

Parrat, F. (2003). Gouvernement d'entreprise. Paris: Dunod.

Rosenstein, S., \& Wyatt, J. G. (1990). Outside Directors, Board Independence, and Shareholder Wealth. Journal of Financial and Economics, 26, 175-192.

Rousseau, S., \& Talbot, A. (2007). Lost in translation? La réforme de la gouvernance d'entreprise au Canada à la suite des scandales financiers américains. In J. L. Navarro, \& G. Lefevre (Eds.), L'acculturation des droits des affaires. Montreal. Quebec: Thémis.

Shleifer, A., \& Vishny, R. W. (1997). A Survey of Corporate Governance. The Journal of Finance, 12(2), 737-783.

\section{Appendix}

Appendix 1. Orporate governance index

\begin{tabular}{|c|c|c|}
\hline & Practices & Measures \\
\hline \multirow{11}{*}{ Board } & Board independence & The board should have a majority of independent directors. \\
\hline & $\begin{array}{l}\text { Chairman of the board } \\
\text { independence }\end{array}$ & The chair of the board should be an independent director. \\
\hline & $\begin{array}{l}\text { Non-duality of the } \\
\text { chairman }\end{array}$ & The president of company is not the chairman of the board. \\
\hline & $\begin{array}{l}\text { Code of Business Conduct } \\
\text { and Ethics }\end{array}$ & The board should adopt a written code of business conduct and ethics. \\
\hline & & \\
\hline & $\begin{array}{l}\text { Charter or mandate of the } \\
\text { board }\end{array}$ & The board should adopt a written mandate \\
\hline & Regular & The board, should be regularly assessed regarding its \\
\hline & Assessments & Effectiveness. \\
\hline & Orientation and Continuing & The board should provide continuing education opportunities for all directors. \\
\hline & Education & \\
\hline & Meetings of Independent & The independent directors should hold regularly scheduled meetings at which \\
\hline
\end{tabular}




\begin{tabular}{|c|c|c|}
\hline \multirow{6}{*}{ Audit committee } & Directors & non-independent directors and members of management are not in attendance. \\
\hline & Financial expert & A board member is designated as a financial expert. \\
\hline & Entirely independent & All the members are independent directors. \\
\hline & Or partially independent & At least should have a majority of independent directors. \\
\hline & Charter or mandate & Should have a written mandate. \\
\hline & Three members & Should have at least 3 members. \\
\hline \multirow{4}{*}{$\begin{array}{l}\text { Nomination } \\
\text { committee }\end{array}$} & Financial expert & A committee member is designated as a financial expert. \\
\hline & Entirely independent & All the members are independent directors. \\
\hline & Or partially independent & At least, the committee should have a majority of independent directors. \\
\hline & Charter or mandate & Should have a written mandate. \\
\hline \multirow{6}{*}{$\begin{array}{l}\text { Compensation } \\
\text { committee }\end{array}$} & Financial expert & A committee member is designated as a financial expert. \\
\hline & Entirely independent & All the members are independent directors. \\
\hline & Or partially independent & At least should have a majority of independent directors. \\
\hline & Charter or mandate & Should have a written mandate. \\
\hline & Financial expert & A committee member is designated as a financial expert. \\
\hline & Entirely independent & All the members are independent directors. \\
\hline \multirow{5}{*}{$\begin{array}{l}\text { Corporate } \\
\text { governance } \\
\text { committee }\end{array}$} & Or partially independent & At least should have a majority of independent directors. \\
\hline & Charter or mandate & Should have a written mandate. \\
\hline & Financial expert & A committee member is designated as a financial expert. \\
\hline & Entirely independent & All the members are independent directors. \\
\hline & Or partially independent & At least should have a majority of independent directors. \\
\hline \multirow{2}{*}{$\begin{array}{l}\text { Other board } \\
\text { committee }\end{array}$} & Charter or mandate & Should have a written mandate. \\
\hline & Financial expert & A committee member is designated as a financial expert. \\
\hline
\end{tabular}

Notes

Note 1. May 2005 report extracted from the Department of Finance Canada (www.fin.gc.ca/activity/pubs/fostering_05f.html).

Note 2. National Policy 58-201.

Note 3. Toronto Stock Exchange Committee on Corporate Governance in Canada, Where Were the Directors? Guidelines for Improved Corporate Governance in Canada, Toronto, 1994.

Note 4. The charter should define the roles and responsibilities of the board of directors.

Note 5. Given that the regulation on the audit committee is mandatory, the score for this committee has very little discriminating power. As only six firms in the sample failed to fully conform to this regulation, the analysis of this score is not relevant.

Note 6. National Instrument 52-110 (Audit Committees) and National Policy 58-201 (Corporate Governance) Guidelines the same regulations were adopted by the Ontario Securities Commission.

\section{Copyrights}

Copyright for this article is retained by the author(s), with first publication rights granted to the journal.

This is an open-access article distributed under the terms and conditions of the Creative Commons Attribution license (http://creativecommons.org/licenses/by/3.0/). 